\title{
VISIT PATH PATTERN OF THE HONEYBEE (Apis mellifera L.) ON THE SUNFLOWER CAPITULUM -CORRESPONDENCE WITH THE LOCATION OF SEEDLESS AND INCOMPLETELY DEVELOPED FRUITS
}

\begin{tabular}{l}
\hline Hernández, L.F. ${ }^{* 1,2}$ \\
\hline${ }^{1}$ Laboratorio de Morfología Vegetal. Depto. de Agronomía, UNSur. \\
Bahía Blanca, 8000, Argentina \\
La Plata, 1900, Argentina
\end{tabular}

Received: November 23, 2007 Accepted: January 10, 2008

SUMMARY

The occurrence of fruits with absent or poorly developed embryo, also defined as seedless or incompletely developed fruits (IDF), significantly reduces the sunflower yield. Failures in pollination, fertilization and physiological or morphological defects in the ovary and embryo, either post-pollination or post-fertilization genotype- and/or ambient-induced, are most common reasons for the development of this type of fruits.

A detailed study of the visit path pattern of diurnal pollinators in the crop, mainly honeybees (Apis mellifera L.), showed that there was a significant negative correlation $\left(\mathrm{r}^{2}=-0.61 ; \mathrm{p}<0.05\right)$ between the areas covered by foraging paths (ACP), with the total IDF counted in the capitulum.

Almost a complete limitation of insect visitation (0-30\% ACP) resulted in poor seed set and IDF percentage ranging from 10 to $17 \%$. Partial limitation of the insect visitation (60 to $90 \%$ ACP) diminished the number of IDF to 5 to $9 \%$. Its is concluded that as much as $30 \%$ or more of the capitulum's area must be covered by bee visits to minimize the development of IDF.

Key words: Apis mellifera, foraging, Helianthus annuus, pollen, seed set, sunflower

\section{INTRODUCTION}

The sunflower [Helianthus annuus L., var. macrocarpus (DC.) (Ckll.)] is an important crop for the production of oil seed in temperate regions of Argentina. The total number of fruits (cypselae) per plant that fully develop seed (kernel) is one of

* Corresponding author: Fax: +54 - 0291 - 4595127; e-mail: lfhernandez@uns.edu.ar 
its most important yield components for both seed and oil production (Connor and Hall, 1997).

At maturity, the head (capitulum) of self-sterile and self-fertile sunflower cultivars usually show a set of fruits with a different degree of pericarp and embryo development. In most of them, the embryo reaches its full size filling the internal cavity of the ovary. These fruits can be defined as fully developed (FDF) (Lindström et al., 2006; 2007). Nevertheless many mature fruits often contain ovules that did not fully develop into seeds. In those fruits, seed growth processes stop at different moments, leaving the fruit with an incompletely developed pericarp and/or seed (seedless or incompletely developed fruits or IDF; Lindström et al., 2004). So, even though IDF generally tend to be considered as "seedless" or "empty", in some of them the embryo can reach a certain level of development (Alkio et al., 2002; Alkio and Grimm, 2003; Lindström et al., 2004). IDF can be randomly distributed all over the capitulum surface ( Hernández et al., 2002; Lindström et al., 2004). Most of them are easily identified because as a consequence of the arrested embryo and pericarp development, the hull is usually compressed by neighboring fruits showing an abnormal external collapsed appearance (Figure 1). Others are most difficult to identify because the hull partially develops without any seed inside.


Figure 1: Location and external appearance of IDF in the peripheral region of the capitulum. (A) Four days after the first anthesis; (B) At physiological maturity (Schneiter and Miller, 1981), 48 days after the first anthesis. Arrows indicate the location of the pre-defined IDF observed in A; they are less developed than those surrounding them, with a darker coloration of the pericarp. In $B$, note the contrast of the pericarp color of the IDF (arrows) and the decrease in their development in comparison with those surrounding them. The scale for both figures is $1 \mathrm{~cm}$.

The fertilization histories of those fruits cannot be determined externally. Thus, visual inspection of developing and mature fruit contents, sometimes aided by a dissecting microscope, is the most common mean for distinguishing FDF from IDF. 
The real causes of the origin of IDF are unknown but several proximate mechanisms that have been put forth to explain the low seed to ovule ratio in many species of the Angiospermae can be applied to sunflower. Their origin could be attributed to environmental, physiological and/or anatomical causes as well as to lack of pollination or to post pollination failures during the early development of embryos (Gillaspy et al., 1993; Connor and Hall, 1997; Cantagallo et al., 2004; Hernández and Bellés, 2005). Most of the times, poor seed set or unfilled fruits occur mainly due to inadequate pollination (Birch and van der Sandt, 1985), competition for resources between developing ovaries or vascular deficiencies at the ovary-receptacle interphase (Durrieu et al., 1985; Hernández and Orioli, 1991; Hernández and Palmer, 1992; Alkio and Grimm, 2003).

Because the development of IDF is a cause of significant reductions in seed and oil production of sunflower, determining the reasons and the degree of this reduced fecundity, are important goals in studies of sunflower breeding.

Sunflower pollen is heavy and sticky. It cannot be carried by wind so pollen transport by insects is necessary for improved seed set (Birch and van der Sandt,1985; Skinner, 1987; Medan et al., 2003; DeGrandi-Hoffman and Chambers, 2006). Several studies have shown that the foraging activity of the honeybee (Apis mellifera L.) can increase seed set and yield (Parker, 1981a; Fell, 1986; Medan et al., 2003; DeGrandi-Hoffman and Chambers, 2006).

The foraging pattern of the honeybee on the self-fertile sunflower capitulum has not been deeply studied and its relationship with seed set has not been totally established. Giurfa and Núñez (1993) observed in capitula of Carduus acanthoides that the foraging pattern is irregular and that the insect visits each flower once. Previously Parker (1981b) demonstrated the random paths followed by honeybees over a flowering sunflower head but he did not quantify them and the pattern of paths created by all daily visitors over a head was not further described.

The aim of the present work was to determine an association of the position of IDF within the capitulum with the paths of visits of one of its main daily pollinators. It is proposed that a fraction of the IDF is due to the absence of pollinators visits. Therefore, we studied the relationship between the paths of daily visits of honeybees on the capitulum and the pattern of incompletely developed fruits within capitula of cultivated sunflower.

\section{MATERIALS AND METHODS}

\section{Plant material and cultural techniques}

The experiment was carried out at the Agronomy Department-UNSur, Bahía Blanca, Argentina (lat. S $38^{\circ} 45^{\prime}$; long. W $62^{\circ} 11^{\prime}$ ). The soil at the field location was a Typic Ustipsamment (USDA, 1999). A low self-fertile experimental sunflower genotype, provided by Dow Agrosciences of Argentina, was sown starting the first week 
of October, at three dates separated by 5-day intervals, in order to obtain plants at the beginning of flowering (first anthesis, according to Schneiter and Miller, 1981) during several consecutive days and to study them individually. Preliminary trials demonstrated that this sunflower cultivar produced more than $40 \%$ seedless fruits per capitulum when plants were caged to prevent insect interaction during flowering (L.F. Hernández, unpublished). It was also chosen because the external color of the fruit's pericarp, white at early stages of fruit development and black-striate at maturity, facilitates the identification of IDF (Figure 1). After seedling emergence, plant density was adjusted to 5.6 plants $/ \mathrm{m}^{2}$. The crop was managed according to conventional agronomical practices (Pereyra and Farizo, 1981). Weeds and pests were adequately controlled. Water was supplied by drip irrigation. Forty bee hives were located near the experimental plot was $(500 \mathrm{~m})$. This was an adequate population of honeybees, which ensured that visitation at flowering was highly intense. At mid-anthesis, about 4.0 honeybee visits were counted on average at 40 open capitula in $15 \mathrm{~min}$.

Daily records of temperature and solar radiation were obtained from a meteorological station located $800 \mathrm{~m}$ from the experimental field (Figure 2).



Figure 2 Mean daily temperature $\left(0 ;{ }^{\circ} \mathrm{C}\right)$ relative humidity (๑; \%) and rain ( $\mathrm{mm}$, black bars) for the experimental location. The segment between start and end arrows indicate the time when all the observation on capitula were made.

\section{Plant selection and pollinator visits observations}

Two plants displaced 4 to 5 days in time for each seeding date were randomly selected in the stand $(n=6)$. Before the first anthesis, the selected plants were staked, orienting the side of the capitulum with flowers eastwards. At first anthesis, when the ray floret corollas allowed the visualization of the first circle of the disc flowers, the capitulum diameter was measured and four reference points were marked at the periphery using color pearl head pins. The capitulum of one plant at 
a time was then continuously recorded using a digital camera. The filming process took 2 to 3 days, from first anthesis and until the first 4-6 rows of peripheral flowers finished opening. Daily and continuous observations of plants, from 8.00 a.m. to 5 p.m., allowed interrupting filming when visitors were absent (for instance, at midday). Honeybee foraging on a head was continuously watched until bees left that head. At dusk, the inflorescence was covered with mesh bags to avoid the action of night pollinators. This also ensured that nectar could accumulate and possible scent-marks evaporate (Giurfa and Nuñez, 1992; Gawleta et al., 2005). After the study was completed, the observed plant was protected during the night until harvest and the procedure was repeated with another plant that has reached the stage of first anthesis. No study was conducted on the center of the capitulum because the poor seed set in this region or the occurrence of IDF can have multiple causes and the results are more likely to be masked by unknown reasons.

\section{Data processing}

Each digital file saved in MOV format was processed digitally for each observed plant $(n=6)$ using VideoPoint vers. 2.5 (Lenox Softworks, Lenox, MA) software to define, in Cartesian coordinates, the foraging routes of all the diurnal pollinators. Only honeybees and sporadically carpenter bees (Xylocopa sp.) were observed, the latter also being filmed. The bee's thorax was the reference point of movement to digitalize the route followed by the insect during its visit (arrival-departure) to the capitulum surface. The program allowed to digitalize the routes followed simultaneously by more than one bee. The landmarks on the capitulum allowed the correct location and correspondence of the recorded paths on the capitulum at anthesis and at maturity (Figure 2).

Each image of the capitulum was fractionated in 60 sectors and the pixel density corresponding to the foraging routes in each sector was quantified (Figure 3).

The routes followed by the honeybee were graphically represented for each capitulum on an axis of Cartesian coordinates and the pixel density was analyzed using a plug-in specially designed to operate with the software Object-Image 2.21 (http://simon.bio.uva.nl/object-image.html; Vischer et al., 1994) on a Macintosh platform. After calculating the area of each sector of the capitulum, the average pixel density was estimated for each sector and a covering map or "density map" (pixels \% per sector) was drawn for each capitulum of each of the six observed plants (Figure 3).

The visitation density was analyzed considering the route followed by the bee when walking on the capitulum. Flying bees were not considered. As the tracing of the followed routes was not corrected by the width of the bee's thorax, which can reach an average value of $3.0 \mathrm{~mm}$ (Winston, 1991), it was not considered whether the bee, during its movement, could carry away pollen from adjacent anthers or shed pollen attached to its body. Nevertheless, the width of the route followed by the bee can be estimated as approximately the diameter of an open corolla. 


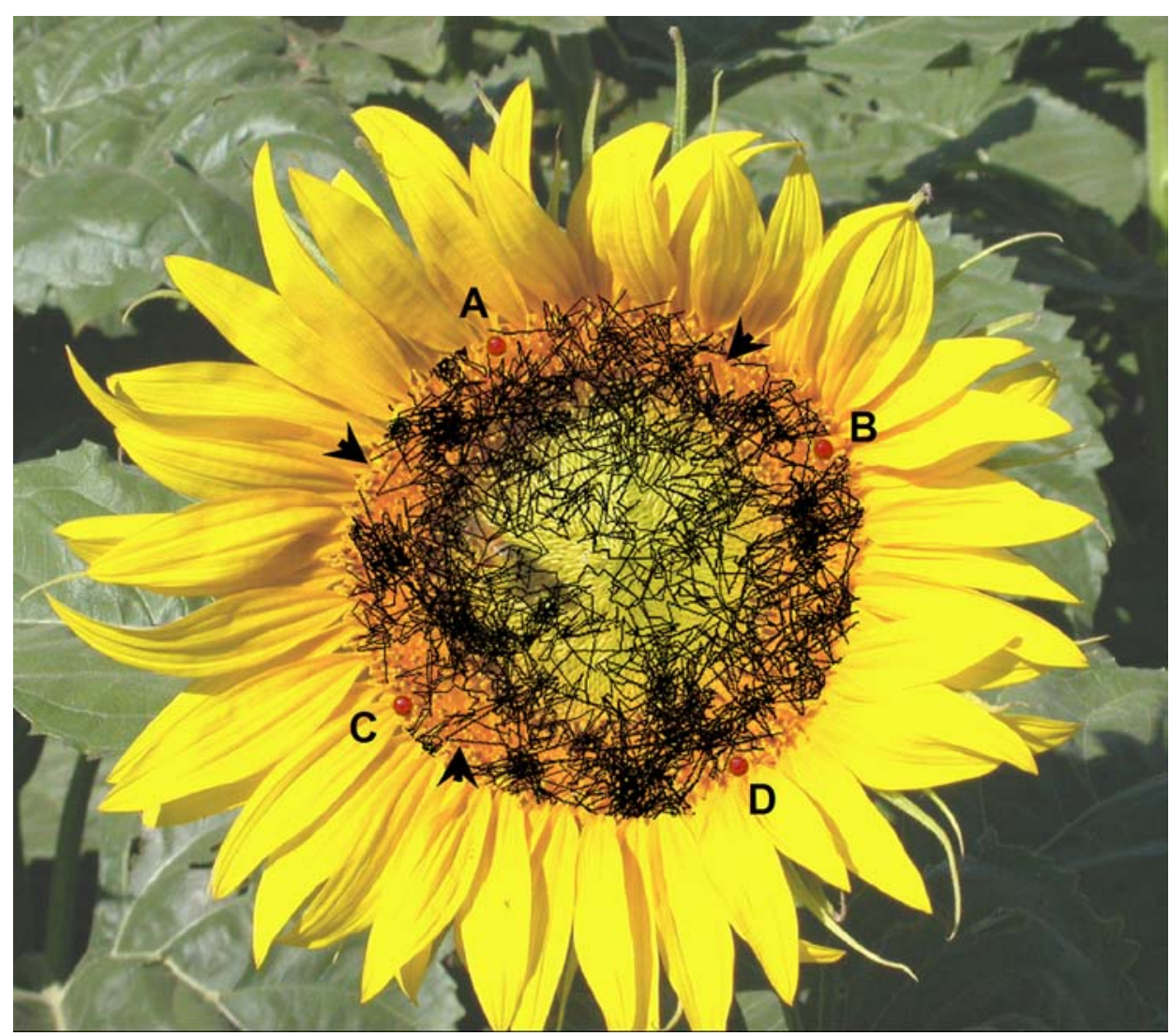

Figure 3: Pattern of routes of daily visits of honeybees (Apis mellifera L.) and, in less proportion, carpenter bees (Xylocopa sp.) during two consecutive days after the first anthesis, on the capitulum of one of the 6 plants studied in this work. The tracing of the image of 2 pixel width was accomplished after processing the digital images with the software VideoPoint. Arrows show some of the unvisited regions. The red circles noted with letters $A, B, C$ and $D$ correspond to the reference points defined on the capitulum and marked with color pearl head pins. The routes followed towards the central region of the capitulum were not considered in this study because these flowers were not open at the time of the analysis.

At harvest, the location of the IDF on each mature capitulum was defined for each plant properly identified, using the reference landmarks (Figure 1). The IDF proportion was calculated by dividing each capitulum into sectors. The IDF proportion was then compared with the intensity of visitations per each sector or area covered by paths (ACP; Figures 4 and 5).

When the obtained data were subjected to an analysis of linear and non-linear correlation, the differences between the treatments and sampling date means were compared by the LSD test. 




Figure 4: Areas covered by pollinator paths $(A C P \%)$ per sector $(n=60)$ in which each capitulum of the 6 studied plants was divided to conduct the analysis. ACP (\% of total area of each sector) values, obtained according to the methodology described in the text, correspond, for this figure, to the capitulum of Figure 3. The black points noted with letters $A, B, C$ and $D$ correspond to the reference points defined in each capitulum (see Figure 3).

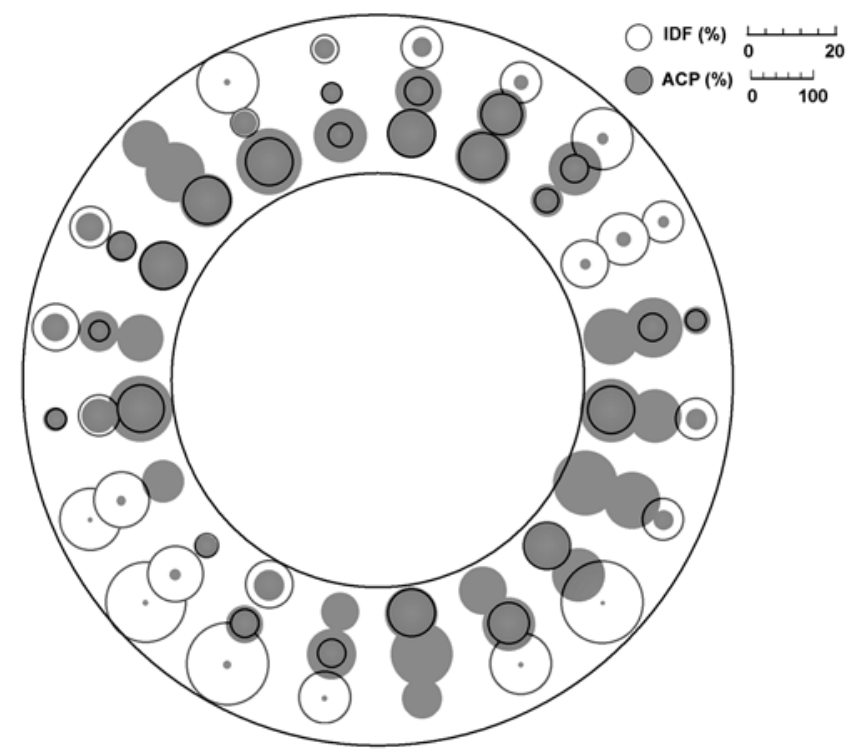

Figure 5: Emerging relationship between the area covered by visit paths ( $\bullet$; ACP\%) and the IDF\% (O) produced in each sector for the capitulum of Figure 3, numerically elaborated form data generated from Figure 4. The scales indicate the length of the diameter of each circle with the percentage magnitude of each variable. 


\section{RESULTS}

The main floral visitors in our observations belonged to the order Hymenoptera (100\% of total visits). Only two types of Hymenoptera visited the flowers during the day: Apis mellifera L., which made most of the visits (98\%), and Xylocopa sp. (2\%). The complete pattern generated by the routes followed on the anthesis ring (the distance defined between the row of open flowers at first anthesis and that produced the day after first anthesis) during two consecutive visiting days for one of the six studied plants is shown in Figure 3. The density of visits per capitulum sector calculated according to the described methodology is presented in Figure 4. The relationship between the percentage of areas covered by paths (ACP\%) and the percentage of IDF per sector in the same plant is presented in Figure 5.

It can be seen that the path density is not homogeneous, showing zones with high and very low densities and some unvisited zones (Figures 3 and 4). In the same plant, the absence of visits or a low density of visits in a sector caused an increase in the percentage of IDF (Figure 5).

The results from the analysis of the 6 plants in which the capitula were separated in 60 sectors according to Figure 3, giving the relationship between the area covered by foraging paths and the percentage of IDF in each sector, are shown in Figure 6.

An inverse relationship was observed in the area covered by foraging paths (ACP\%) and IDF\% ranging from $0 \%$ to $30 \%$ of the area covered. Above this value, between $30 \%$ and $100 \%$ ACP, there was no correlation between the two parameters (Figure 6).

However, three segments of the relationship between the area covered by paths ACP\% and the IDF\% could be determined. Thus, between 0 and $30 \%$ ACP, an inverse relationship was observed $\left(\mathrm{r}^{2}=0.61 ; \mathrm{n}=91 ; \mathrm{p}<0.05\right)$ which could be fitted in a quadratic equation (Figure 6). Above this value, between 30 and $100 \%$ ACP, IDF magnitudes were presented in two broadly fluctuating levels. One of them fluctuated from 30 to $100 \%$ ACP and another from 56 to $100 \%$ ACP (Figure 6).

\section{DISCUSION}

The sunflower is considered a cross-pollinated crop, originally self-sterile (Charlet et al., 1997). Most cultivated varieties are self-fertile which means that florets can set seed when they are pollinated with pollen from the same flower head. Nevertheless some cultivated varieties are partially self-sterile and require pollen from another plant. Within-head selfing usually results in lower seed set, smaller seeds, lower oil content, and a lower germination rate compared to open crossing (McGregor, 1976). Thus, cross-pollination is advantageous except in highly self-fertile varieties. 


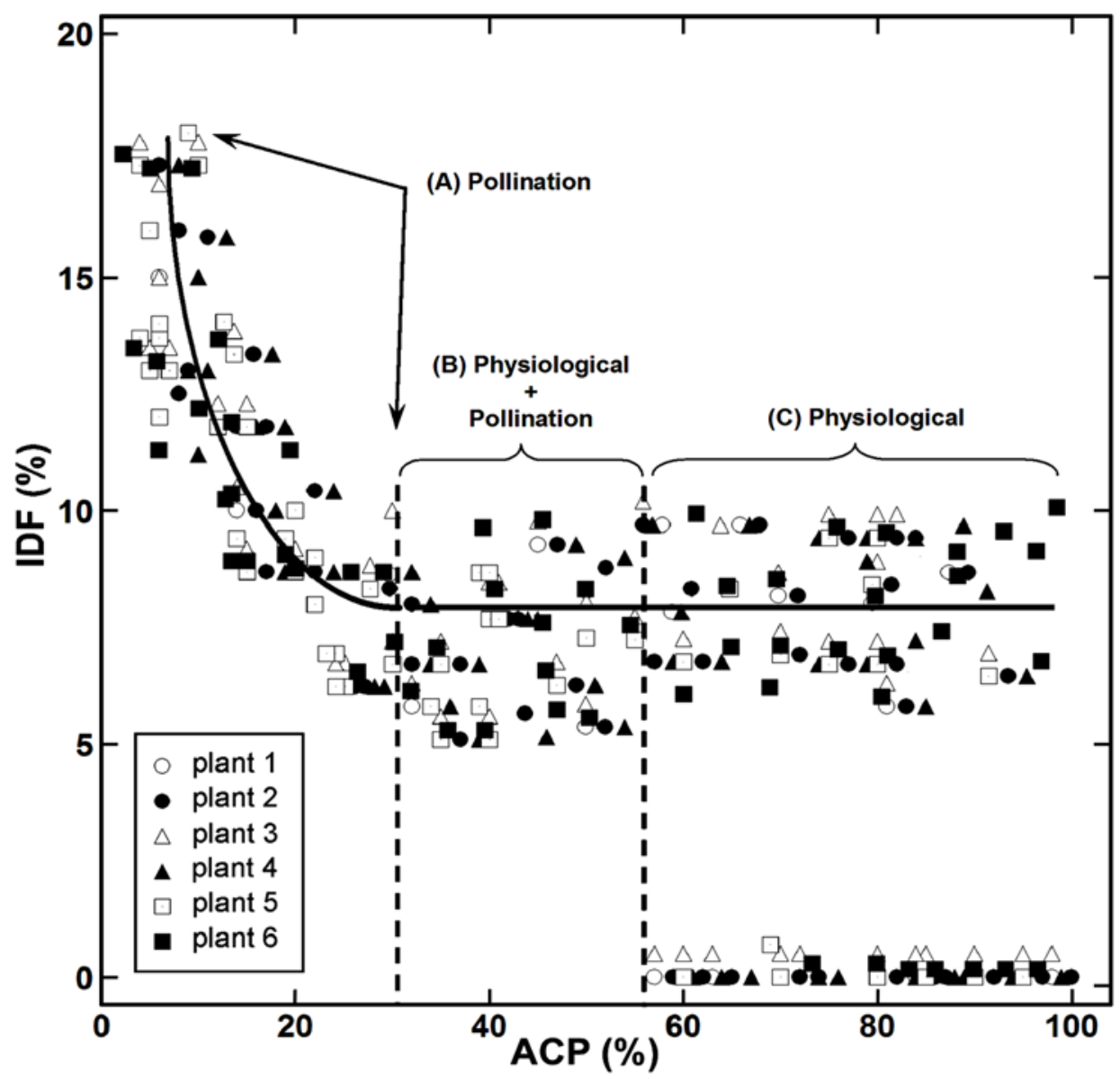

Figure 6: Relationship between the area covered by paths (ACP\%) and the total percentage of incompletely developed fruits (IDF\%) observed in each sector $(n=60)$ in which each capitulum of the 6 sunflower plants was divided for analysis. The sum of observations of $I D F \%$ is separated in ranges from $0 \%$ to $30 \%, 30 \%$ to $60 \%$ and $60 \%$ to $100 \%$ of ACP to define three types of causes acting in the development of IDF: (A) mainly pollination failures, associated with the lack of pollinator visits $\left(0-30 \%\right.$ ACP $\left.; I D F \%=31.48 \times A C P^{-0,43} ; r^{2}=-0.61 ; n=91 ; p<0.05\right)$, (B) physiological plus pollination failures and $(C)$ mainly physiological causes.

Fruit set failures can result from a number of events preventing the development of the flower into a mature fruit (Stephenson, 1981; Stephenson, 1992). Lack of sufficient pollen loads on the stigma to fertilize all the flowers (Wilson and Schemeske, 1980; Snow, 1982; Gross and Werner, 1983; Schemske and Pautler, 1984; Weins, 1984; Zimmerman and Pyke, 1988) and physiological and/or anatomical alterations and source limitations to provide for seed development (Wilson and Schemske, 1980; Stephenson, 1981; Wyatt, 1981; Lee and Bazzaz, 1982; Weins, 
1984; Zimmerman and Pyke, 1988; Burd, 1994; Connor and Hall, 1997) have been most commonly blamed as causes for a low seed set.

In sunflower, even though the competition for resources among the ovaries within the developing head can cause embryo abortion or failures in seed set (Stephenson, 1981; Bawa and Webb, 1984; Lee, 1988; Thomson, 1989), it is viable pollen that has to be adequately transported to the stigma to accomplish pollen tube growth in the pistil and fertilize the ovules (Connor and Hall, 1997).

According to the "non-uniform pollination hypothesis" (Thomson, 1985, 1989; Berry and Calvo, 1991; Brunet and Charlesworth, 1995) the observed patterns of IDF in the mature capitula may be attributable to variation in pollen receipt over the inflorescence flowering period. Specifically, the relatively low seed set in central areas of the sunflower capitulum has usually been attributable to insufficient pollen quantity or pollinators visits. Why are some florets left unvisited in the peripheral regions of the capitulum cannot be answered by the information obtained in this work. Recently, Giurfa (2004) demonstrated that the honeybee can discriminate color and regarding this, it has been noticed (L.F. Hernández, unpublished) that some floret corollas in different capitulum locations of recently open florets show comparatively different color intensity compared with their neighbors. In addition to visual cues, bees also perceive and use olfactory cues in floral choice (von Frisch, 1919; Laska et al., 1999; Giurfa and Nuñez, 1992). It is also known that honeybees avoid probing flowers that have been recently depleted by conspecifics, presumably repelled by odors (foraging scent marks) deposited by the previous visitor (Giurfa and Nuñez, 1992; Gawleta et al., 2005). Once its nectar load has been depleted the bee does not return to the same flower. Probably if this is the case, the reason to leave some disc florets unvisited (Figures 3-4) could be related with its proximity to already visited neighbor florets.

In this work, climatic conditions during capitulum maturation were optimal. No rain occurred during the observation period, which could lead to pollination failures by pollen lixiviation and air temperature was always near or below $30^{\circ} \mathrm{C}$ (Figure 2), a threshold level known to affect sunflower pollination (DeGrandi-Hoffman and Chambers, 2006).

Sunflower genotypes vary in their attractiveness to honeybees. Short corolla length, unpigmented stigmas, many stomata on the nectary, and high sucrose content of the nectar are preferred by honeybees. If a flower is never visited, it could be an indication that the floret per se is responsible for the lack of attractiveness by some intrinsic difference that make it special and "unvisitable" compared with the surrounding ones. Sammataro et al. (1984) found intragenotipic differences in the quality, quantity and anatomy of nectaries (Sammataro et al., 1985). Perhaps interplant differences could also exists.

The availability of resources can vary in both space and time for an individual flower, due to local competition for resources (Stephenson, 1981; Wyatt, 1981). Hence, within a single plant, resources may be limited for some flowers but not for 
others. Nevertheless we do not think this is the case for the external flowers of the sunflower capitulum. It has been observed that at early anthesis stages, recently opened flowers are not deprived from assimilate supply (Hernández and Orioli, 1991; Alkio et al., 2002; Alkio and Grimm, 2003).

Finally, according to the "architectural effects hypothesis", the pattern of seed production can also be provoked in some plants by intrinsic factors limiting the ripening of ovules located in some positions (Diggle, 1995). The proximate causes of these architectural effects are still unknown (Diggle, 1997), although cumulating evidence is showing that it can have important effect on the observed pattern of seed production (Medrano et al., 2000 and references therein).

Regarding the completely hollow fruits that develop pericarp but not seed, it should be remembered that parthenocarpy, the formation of seedless fruit, occurs naturally in many species (George et al., 1984) and can be artificially induced by hormone application, mainly auxins and gibberellins (Schwabe and Mills, 1981; García-Martínez and Hedden, 1997). In natural parthenocarpy, it has been suggested that the expression of parthenocarpic genes can affect the pattern of hormone production, transport and/or metabolism leading to hormone levels in the ovary capable of promoting growth even in the absence of pollination and fertilization (Nitsch, 1970; Gillaspy et al., 1993).

The analysis of Figure 6 revealed, at first glance and considering the conditions under which the experiment and the observations were conducted, three cause and effect intervals. Assuming that no contribution from other pollinators occurred in the period from anthesis to fertilization, three factors could be defined which play a role in the generation of IDF. From $0 \%$ to $30 \%$ of ACP, the negative correlation found between ACP\% and IDF\% $\left(r^{2}=-0.61\right)$ suggests that within this range, the lack of pollen had a high incidence causing an absence of pollinator visits to that region (Figure 6); from 30\% ACP and above, this value, i.e., the stable level of IDF fluctuating from 5 to $10 \%$, suggests that we have to consider two variables.

On the one hand, the absence of pollen could be maintained at $60 \%$ in those regions due to a low occurrence of bee visits, but on the other hand, factors related to the floral biology (physiological factors) of the studied genotype might be in action (Figure 6). Above $60 \%$ of ACP, the absence of IDF (0\%) in several sectors (Figure 6 ) and again the occurrence of sectors with a fluctuating level of IDF\% ranging from 5 to $10 \%$ of the total value would explain that the IDF generated in that region was produced due to physiological causes, which were neither detected nor studied in this present work but are probably characteristic for the low self-compatibility of the genotype used. Given the present information, it would be expected that in sunflower genotypes with high self-compatibility, the IDF fraction, although fluctuating, could descend to levels under $5 \%$ per sector. 


\section{CONCLUSIONS}

In this work, fruit-set in sunflower was found to be positively correlated with the proportion of flowers that hosted honeybees when its value of bee visits was lower than $30 \%$.

The correlation between the percentage of IDF per sector and the ACP (\%) over $30 \%$ was weak (Figure 6), probably because it was masked with other variables, which would act to generate IDF.

Another weakness is the fact that the ACPs were sampled only after the bees settled during the day, without quantifying the behavior of other pollinators during the night.

Nevertheless, the positive relationship between the density of foraging routes and the development of IDF in several areas of the capitulum demonstrate the important role of day-sheltering bees as sunflower pollinators. Unvisited areas are positively correlated with the presence of seedless or incompletely developed fruits at maturity. This also suggests that some flowers from those areas are inclined to show absence or delay in pollination with respect to the adjacent flowers.

Due to night covering, we could assume that nocturnal pollinators would substitute the lack of visited sites by areas that bees did not visit during the day. Nevertheless if a deficiency in the nectary number or floret functionality occurred, these sites would not be visited at night either.

\section{ACKNOWLEDGEMENTS}

This work was funded by grants to L.F.H. of the Agencia Nacional de Promoción Científica y Tecnológica and the Argentine Sunflower Association (ANPCyT-ASAGIR, PICTOS-13151), the Secretaría Gral. de Ciencia Tecnología (SeGCyT-UNS) and the Comisión de Investigaciones Científicas (CIC, LaPlata) Argentina.

The valuable comments on the manuscript made by Dr. D. Sammataro (Dept. Entomology, Univ. Arizona USA) are greatly appreciated. The invaluable cooperation of $N$. Vischer (Swammerdam Institute for Life Sciences, University of Amsterdam) in developing a special plug-in for his software Object Image and Mrs. G.M. Abrego for collaborating in the field experiments are also specially appreciated. Sunfower seed was kindly provided by Dow Agrosciences of Argentina.

\section{REFERENCES}

Alkio, M., Diepenbrock, M. and Grimm, E., 2002. Evidence for sectorial assimilate supply in the capitulum of sunflower (Helianthus annuus L.). New Phytol. 156: 445-456.

Alkio, M. and Grimm, E., 2003. Vascular connections between the receptacle and empty achenes in sunflower (Helianthus annuus L.). J. Exp. Bot. 54: 345-348. 
Barrett, S.C.H., 1988. The evolution, maintenance, and loss of self-incompatibility systems, pp. 98-124. In: J. Lovest-Doust and L. Lovest-Doust (eds.), Reproductive Ecology of Plants, Oxford University Press, Oxford, UK.

Bawa, K. and Webb, C.J., 1984. Flower, fruit and seed abortion in tropical forest trees. Implications for the evolution of paternal and maternal reproductive patterns. Am. J. Bot. 71: 736-751.

Berry, P.E. and Calvo, R.N., 1991. Pollinator limitation and position dependent fruit set in the high Andean orchid Myrosmodes cochleares (Orchidaceae). Plant Systematics and Evolution 174: 93-101.

Birch, E.B. and van der Sandt, J.C., 1985. Bee pollination of sunflower. Proc. XI International Sunflower Conf., Mar del Plata, Argentina, ISA, pp. 255-260.

Brunet, J. and Charlesworth, D., 1995. Floral sex allocation in sequentially blooming plants. Evolution 49: 70-79.

Burd, M., 1994. Bateman's principle and plant reproduction: the role of pollen limitation in fruit and seed set. Bot. Rev. 60: 83-139.

Cantagallo, J.E., Medan, D. and Hall, A.J., 2004. Grain number in sunflower as affected by shading during floret growth, anthesis and grain setting. Field Crops Res. 85: 191-202.

Connor, D.J. and Hall, A.J., 1997. Sunflower Physiology, pp. 113-182. In: A.A. Schneiter, [ed.], Sunflower Technology and Production, Agron. Ser. 35, ASA, CSSA, SSSA, Madison, WI, USA.

Charlet, L.D., Brewer, G.J. and Franzmann, B., 1997. Insect pests. pp. 183-261. In. A.A Schneiter [ed.], Sunflower Technology and Production. Agron. Ser. 35. Am. Soc. Agron., Madison, WI.

DeGrandi-Hoffman, G. and Chambers, M., 2006. Effects of honey bee (Hymenoptera: Apidae) Foraging on seed set in self-fertile sunflowers (Helianthus annuus L.). Environ. Entomol. 35: 1103-1108.

Diggle, P.K., 1995. Architectural effects and the interpretation of patterns of fruit and seed development. Ann. Rev. Ecol. Syst. 26: 531-542.

Diggle, P.K., 1997. Ontogenetic contingency and floral morphology: the effects of architecture and resource limitation. Int. J. Plant Sci. 158 (supplement): S99-S107.

Durrieu, G., Percie du Sert, C. and Merrien, A., 1985. Anatomie du capitule de tournesol consequences sur la nutrition des akenes. Proc. XI Int. Sunflower Conf., Mar del Plata, Argentina, ISA. pp. 7-12.

Fell, R.D., 1986. Foraging behaviors of Apis mellifera L. and Bombus ssp. on oil sunflower (Helianthus annuus L.). J. Kansas Entomol. Soc. 59: 72-81.

Frisch, K. von. 1919. Über den Geruchsinn der Biene und seine blütenbiologische Bedeutung. Zool. Jahrb. 37: 1-238.

García-Martínez, J.L. and Hedden, P., 1997. Gibberellins and fruit development, pp. 263-286. In: F.A. Tomás-Barberán and R.J. Robins [eds.], Phytochemistry of Fruit and Vegetables. Clarendon Press, Oxford.

Gawleta, N., Zimmermann, Y. and Eltz, T. 2005. Repellent foraging scent recognition across bee families. Apidologie 36: 325-330.

George, W.L., Scott, J.W. and Splittstoesser, W.E., 1984. Parthenocarpy in tomato. Hortic Rev. 6: $65-84$

Gillaspy, G., Ben-David, H. and Gruissem, W., 1993. Fruits: a developmental perspective. Plant Cell 5: 1439-1451.

Giurfa, M. and Núñez, J.A., 1992. Honeybees mark with scent and reject recently visited flowers. Oecologia 89: 113-117.

Giurfa, M. and Núñez, J.A., 1993. Efficient floret inspection by honeybees in capitula of Carduus acanthoides. Ecogical Entomol. 18: 116-122.

Giurfa, M., 2004. Conditioning procedure and color discrimination in the honeybee Apis mellifera. Naturwissenschaften 91: 228-231.

Gross, R.S. and Werner, P.A., 1983 Relationships among flowering phenology, insect visitors, and seed set of individuals: experimental studies on four co-occurring species of golden rod [Solidago: compositae]. Ecological Monographs 53: 95-117.

Hernández, L.F. and Orioli, G.A., 1991. Role of different leaves of the sunflower (Helianthus annuus L.) plant during the grain filling period (in Spanish). Turrialba 41: 330-334.

Hernández, L.F. and Palmer, J.H., 1992. Incorporation of ${ }^{14} \mathrm{C}$ labeled metabolites into the developing sunflower capitulum. Proc. XIII International Sunflower Conf., Pisa, Italy, ISA, pp. 564-570. 
Hernández, L.F., Pellegrini, C.N. and Lindström, L.I., 2002. Prediction of the generation of seedless fruits in the sunflower capitulum (Helianthus annuus L.) (in Spanish). XI Latin American Meeting of Plant Physiologists. Punta del Este, Uruguay.

Hernández, L.F. and Bellés, P.M., 2005. Ocurrence of incompletely developed fruits in the sunflower capitulum. Biomechanical approach to explain its causes (in Spanish). III Argentine Sunflower Association Meeting, Buenos Aires, Argentina, ASAGIR.

Laska, M., Galizia, C.C., Giurfa, M. and Menzel, R., 1999. Olfactory discrimination ability and odor structure-activity relationships in honeybees. Chem. Senses 24: 429-438.

Lee, T.D. and Bazzaz, F.A., 1982. Regulation of fruit and seed production in an annual legume, Cassia fasciculata. Ecology 63: 1363-1373.

Lee, T.D., 1988. Patterns of fruit and seed production, pp. 179-202. In: J. Lovett Doust and L. Lovett Doust (eds.), Plant Reproductive Ecology: Patterns and Strategies, Oxford Univ. Press, New York.

Lindström, L.I., García, M.E. and Hernández, L.F., 2004. Morphology and distribution of incompletely developed fruits in sunflower (Helianthus annuus L.) capitula. Proc. XVI Int. Sunflower Conf., Fargo, USA, ISA, pp. 333-337.

Lindström, L.I., Pellegrini, C.N., Aguirrezábal, L.A.N. and Hernández, L.F., 2006. Growth and development of sunflower fruits under shade during pre and early post-anthesis period. Field Crops Res. 96:151-159.

Lindström, L.I., Pellegrini, C.N. and Hernández, L.F., 2007. Histological development of the sunflower pericarp as affected by pre and early post-anthesis canopy shading. Field Crops Res. 103: 229-238.

Nitsch, J., 1970. Hormonal factors in growth and development, pp. 427-472. In A.C. Hulme, (ed.), The Biochemistry of Fruits and Their Products, Vol. II. Academic Press, London.

McGregor, S.E., 1976. Insect pollination of cultivated crops. U.S. Dept. Agric. Handb. 496 p.

Medan, D., Chamer, M., Devoto, M., Montaldo, N.H., Mantese, A.I., Bartoloni, N.J., Roig-Alsina, A. and Leguizamón, S., 2003. Do the argentine sunflowers need pollinators? (in Spanish). II Argentine Sunflower Association Meeting, Buenos Aires, Argentina, ASAGIR.

Medrano, M., Guitián, P. and Guitián, J., 2000. Patterns of fruit and seed set within inflorescences of Pancratium maritimum (Amaryllidaceae): nonuniform pollination, resource limitation, or architectural effects? Am. J. Bot. 87: 493-501.

Parker, F.D., 1981a. Sunflower pollination: abundance, diversity and seasonality of bees and their effect on seed yields. J. Apic. Res. 20: 49-61.

Parker, F.D., 1981b. How efficient are bees in pollinating sunflowers? J. Kansas Entomol. Soc. 54: 61-67.

Pereyra, V.R. and Farizo, C.L., 1981. Girasol. Técnicas de producción. INTA Balcarce, pp 27.

Schemske, D.W. and Pautler, L.P., 1984. The effect of pollen composition on fitness components in a neotropical herb. Oecologia 62: 31-36.

Schneiter, A.A. and Miller, J.F., 1981. Description of sunflower growth stages. Crop Sci. 21 : 901-903.

Schwabe, W.W. and Mills, J.J., 1981. Hormones and parthenocarpic fruit set: a literature survey. Hortic. Abstr. 51: 661-698.

Sammataro, D., Flottum, P.K. and Erickson, E.H., 1984. Factors contributing to honeybee preferences in sunflower varieties. Proc. Sunflower Res. Workshop, Bismark, ND, pp. $20-21$.

Sammataro, D., Erickson, E.H. and Garment, M.B., 1985. Ultrastructure of the sunflower nectary. J. Apic. Res. 24: 150-160.

Skinner, J.A., 1987. Abundance and spatial distribution of bees visiting male-sterile and malefertile sunflower cultivars in California. Environ. Entomol. 16: 922-927.

Snow, A.A., 1982. Pollination intensity and potential seed set in Passiflora vitifolia. Oecologia 55: 231-237.

Stephenson, A.G., 1981. Flower and fruit abortion: proximate causes and ultimate functions. Ann. Rev. Ecol. Syst. 12: 253-279.

Stephenson, A.G., 1992. The regulation of maternal investment in plants. In: C. Marshall and J. Grace [eds.], Fruit and Seed Production: Aspects of Development, Environmental Physiology and Ecology, Cambridge University Press, Cambridge, UK. pp. 151-171.

Thomson, J.D., 1985. Pollination and seed set in Diervilla lonicera (Caprifoliaceae): temporal patterns of flower and ovule development. Am. J. Bot. 72: 737-740.

Thomson, J.D., 1989. Deployment of ovules and pollen among flowers within inflorescences. Evolutionary Trends in Plants 3: 65-68. 
USDA. 1999. Soil taxonomy: a basic system for classifying soils. Soil Survey Staff. Agriculture, Homework, $436 \mathrm{p}$.

Vischer, N.O.E., Huls, P.G. and Woldringh, C.L., 1994. Object-Image: An interactive image analysis program using structured point collection, BINARY, (Bioline), Vol. 6.

Weins, D., 1984. Ovule survivorship, brood size, life history, breeding systems and reproductive success in plants. Oecologia 64: 47-53

Wilson, M.F. and Schemske, D.W., 1980. Pollinator limitation, fruit production and floral display in paw paw (Asimina triloba). Bull. Torrey Bot. Club 107: 401-408.

Winston, M.L., 1991. The Biology of the Honey Bee, Harvard University Press, 281 p.

Wyatt, R., 1981. The reproductive biology of Asclepias tuberosa II. Factors determining fruitset. New Phytol. 88: 375-385.

Zimmerman, M. and Pyke, G.H., 1988. Reproduction in Polemonium: assessing the factors limiting seed set. Amer. Nat. 131: 723-738.

\title{
PATRÓN DEL CAMINO VISITAS DE ABEJAS MELÍFERAS (Apis mellifera L.) EN EL CAPÍTULO DE GIRASOL. CORRESPONDENCIA CON LA UBICACIÓN DE FRUTOS VACIÓS O DE DESARROLLO INCOMPLETO
}

\author{
RESUMEN
}

La aparición de frutos con el embrión ausente o parcialmente desarrollado, definidos también como frutos vacíos o de desarrollo incompleto (FDI), impacta negativamente en el rendimiento del girasol. Entre las razones frecuentemente responsables de la generación de este tipo de frutos, se encuentran las fallas en la polinización y la fertilización y defectos morfológicos o fisiológicos en el ovario y el embrión tanto genotípicos o producidos por condiciones del ambientales, presentados luego de la polinización o la fecundación.

Un estudio detallado del patrón del camino visitas de polinizadores diurnos en el cultivo, principalmente abejas melíferas (Apis mellifera L.), mostró que existe una correlación negativa $\left(\mathrm{r}^{2}=-0.61 ; \mathrm{p}<0.05\right)$ entre el área cubierta por los caminos de visitas (ACV) con el total de FDI visibles en el capítulo.

En sectores del capítulo con una baja presencia de visitas (0-30\% ACV) se observó un total de FDI de entre 10 y $17 \%$. En sectores del capítulo con ausencia parcial de visitas, (60-100\% ACV) el número total de IDF osciló entre 5 y $9 \%$. Se concluye que al menos un $30 \%$ de la superficie del capítulo debe ser cubierta por visitas de abejas para minimizar la generación de FDI.

\section{PATRON DES CHEMINS DE VISITES D'ABEILLES MELLIFÈRES (Apis mellifera L.) SUR LES CAPITULES DU TOURNESOL. RAPPORT AVEC LE PLACEMENT DES FRUITS VIDES OU DE DÉVELOPPEMENT INCOMPLET.}

RÉSUMÉ

La présence des fruits sans embryon ou avec des embryons partiellement développés, définis aussi comme fruits vides ou de développement incomplet (FDI), provoque un impact négatif sur le rendement du tournesol.

Les motifs les plus fréquents de la genèse de ces fruits sont l'échec de la pollinisation et la fertilisation, les défauts morphologiques ou physiologiques de l'ovaire et de 1 embryon, du à causes génétiques ou à des conditions du milieu présentes après la pollinisation et la fertilisation. 
Une étude détaillée sur le patron des chemins de visites des pollinisateurs à la culture du tournesol durant la journée, notamment des abeilles mellifères (Apis mellifera $\mathrm{L}$. ), a montré une corrélation négative $\left(\mathrm{r}^{2}=-0.61 ; \mathrm{p}<0.05\right)$ entre l'aire sillonnée par les chemins de visites (ACV) et le total de FID visibles dans le capitule.

L`absence des visites des abeilles $(0-30 \%$ ACV) a provoqué le surcroît des FID qui ont varié entre 10 et $17 \%$. Les secteurs du capitule avec une quantité des visites entre $60-100 \%$, out présenté un nombre total de FDI entre $5-9 \%$. On peut conclure que an moins le $30 \%$ de la surface du capitule doit être visité pour minimisée l'apparition du FDI. 